\title{
Antibacterial and antiviral activities of chitosan nanoparticles from the American cockroach, Periplaneta americana
}

\author{
Mahmoud T. Mahboub ${ }^{1}$, Mostafa I. Hassan ${ }^{1}$, Ahmed S. Bream $^{1}$, Aly F. Mohamed², Mohammad R. K. Abdel-Samad ${ }^{1 *}$ (1) \\ ${ }^{1}$ Department of Zoology and Entomology, Faculty of Science, Al-Azhar University, Cairo, Egypt. \\ ${ }^{2}$ Holding Company for Biological Products and Vaccines (VACSERA), Giza, Egypt.
}

\section{ARTICLE INFO \\ Received on: 27/08/2021 \\ Accepted on: 11/12/2021 \\ Available Online: 05/03/2022}

Key words:

Antibacterial, antiviral, chitosan nanoparticles, cockroach, Periplaneta Americana.

\begin{abstract}
Globally, bacteria, parasites, and viruses are the most common causes of infectious diseases that endanger human health. The present work aimed to evaluate the antibacterial, antiviral, and virucidal activities of chitosan nanoparticles (CNPs) that were prepared from the American cockroach body, Periplaneta americana. The chitosan was prepared chemically with a $74.51 \%$ degree of deacetylation and then characterized by Fourier transform infrared spectroscopy. CNPs were obtained by ball-milling of chitosan and then characterized by dynamic light scattering and transmission electron microscope (TEM). CNPs inhibit the growth of Escherichia coli, Klebsiella pneumoniae, Staphylococcus aureus, and Bacillus subtilis. By TEM investigation, CNPs caused the deformation and rupture of the selected bacteria. Also, CNPs protected the Vero cells and significantly decreased the infectivity titers of human adenovirus 40 and coxsackie B4 virus. In conclusion, this study indicated that applying the CNPs from the American cockroach is significant in decreasing the risk of infectious microorganisms.
\end{abstract}

\section{INTRODUCTION}

Researchers are studying more renewable materials to satisfy the needs of the global population and the international community in nutrition, medicine, and industry. In medicine, infectious disease prevention and treatment have got a lot of attention (Meng et al., 2021). Bacteria, fungi, parasites, and viruses are the most common causes of infectious diseases (Lashley, 2004). Antimicrobials discovered in constitutive or immune-stimulated insects have paved new paths in the antimicrobial study (Mosaheb et al., 2018).

Generally, insects like cockroaches have recently drawn the attention of researchers due to their enormous biomass, antimicrobial peptide, and potential as protein, lipid, and chitin sources (Kamal et al., 2020; Lee et al., 2019; Mohan et al., 2020). The American cockroach (Periplaneta americana) is a globally widespread species that can be found in tropics, subtropics, and temperate climates. Furthermore, since certain inland regions lack

\footnotetext{
*Corresponding Author

Mohammad R. K. Abdel-Samad, Department of Zoology and Entomology, Faculty of Science, Al-Azhar University, Cairo, Egypt.

E-mail:mrk1323@azhar.edu.eg
}

fishery services, $P$. americana would act as a complement to the chitin raw material (Chen et al., 2021).

Chitin is the second natural polymer after cellulose over the world, and chitosan is chitin that has been deacetylated. Biocompatibility, nontoxicity, and biodegradability are just a few of the benefits of chitosan (Kim et al., 2008; Leceta et al., 2013). Chitosan has antibacterial, antifungal, and antiviral properties (Hassan et al., 2016a). These properties vary depending on the origin source of chitosan (Marei et al., 2016), as well as the degree of deacetylation (DDA\%) and molecular weight (Chatelet et al., 2001; Vinsova and Vavrikova, 2011). Chitosan nanoparticles (CNPs) are attracting a lot of attention for developing new pharmacological and therapeutic drugs with better biodistribution, increased specificity and sensitivity, and lower pharmacological toxicity (Peniche and Peniche, 2011).

The literature on the antiviral activity of chitosan against human viruses is still limited, and most pieces of literature focus on the effect of chitosan on plant viruses. Therefore, the present work aimed to prepare CNPs from the American cockroach, $P$. americana, and investigate the antiviral and virucidal activities of it against human adenovirus 40 (adeno-40) and coxsackie B4 virus, as well as the antibacterial activity. 


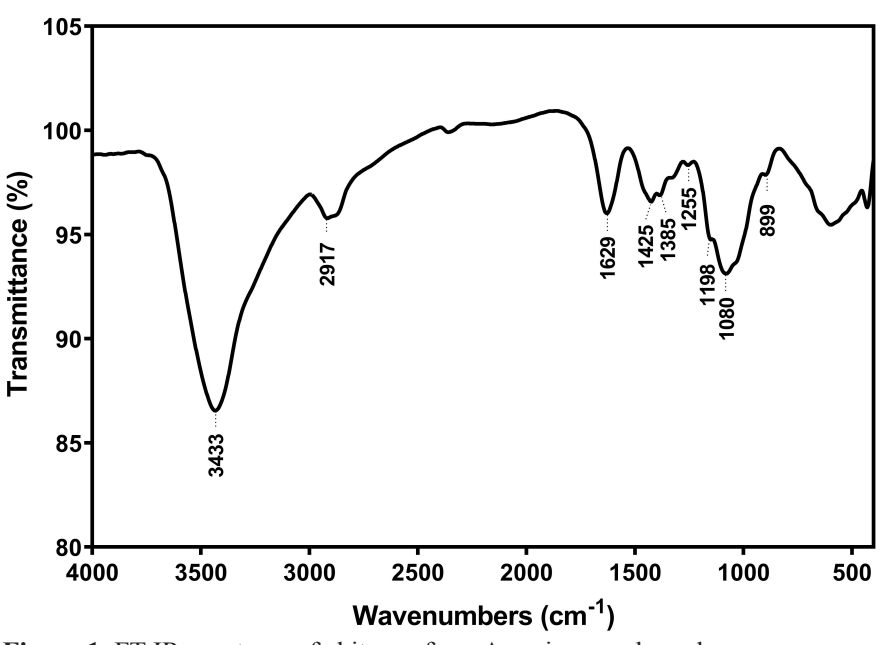

Figure 1. FT-IR spectrum of chitosan from American cockroaches.

\section{MATERIALS AND METHODS}

\section{Collection of cockroaches}

American cockroaches, $P$. americana (Blattodea: Blattidae), were collected from the maintained culture in the Medical Entomology insectary at the Animal House, Zoology and Entomology Department, Faculty of Science, Al-Azhar University, Cairo. The cockroaches were starved before experiments and stored at $-20^{\circ} \mathrm{C}$.

\section{Preparation and characterization of chitosan}

The frizzed cockroaches were dried at $50^{\circ} \mathrm{C}$ and homogenized and sieved to obtain a powder. The powder was deproteinized by stirring with $2.5 \%(\mathrm{w} / \mathrm{v})$ sodium hydroxide $(\mathrm{NaOH})$ with a ratio of $1 \mathrm{~g} \mathrm{:20} \mathrm{ml} \mathrm{for} 6$ hours at $100^{\circ} \mathrm{C}$. The stirred powder was filtered, washed, and dried at $50^{\circ} \mathrm{C}$ for 12 hours. Minerals were removed from the deproteinized powder by stirring with $1 \mathrm{M}$ hydrochloride acid for 2 hours at $75^{\circ} \mathrm{C}$. After the washing and drying, the demineralized powder was decolorized with acetone at $50^{\circ} \mathrm{C}$ for 2 hours and then filtrated, washed, and dried to obtain chitin. Chitosan powder was produced by socking the chitin in $50 \%(\mathrm{w} / \mathrm{v}) \mathrm{NaOH}$ overnight, then stirred for 8 hours at $120^{\circ} \mathrm{C}$, filtrated, washed, and dried.

Chitosan powder was analyzed by Fourier transform infrared spectroscopy (FT-IR Jasco 4100) with a frequency range of 4,000-400 $\mathrm{cm}^{-1}$ at res of $4 \mathrm{~cm}^{-1}$. The DDA was calculated from absorption at 3,450 and 1,655 $\mathrm{cm}^{-1}$ by Equation (1) (Baxter et al., 1992):

$$
\mathrm{DDA} \%=100-\left[\left(A_{1,655} / A_{3,450}\right) \times 115\right]
$$

where $A_{1,655}$ is the absorption of band at $1,655 \mathrm{~cm}^{-1}$ and $A_{3,450}$ is the absorption of band at $3,450 \mathrm{~cm}^{-1}$.

\section{Preparation and characterization of CNPs}

The chitosan powder was ball-milled (Zhang et al., 2014) for 8 hours at 3,400 rpm to obtain CNPs. This process occurred by Retsch Planetary Ball Mill PM 400. The CNPs were investigated with dynamic light scattering (DLS) (Qi et al., 2004) and transmission electron microscope (TEM). As for DLS, suspension of CNPs in water was analyzed by Malvern Mastersizer 2000 (Nano-ZS). For TEM, a few drops from the suspension were dried on a glow-discharged carboncoated microscopy grid at $200 \mathrm{kV}$.

\section{Bacteria, viruses, and cell line}

Selected bacterial strains were obtained from Microbiology Unit at the Regional Center for Mycology and Biotechnology (RCMB). Escherichia coli (RCMB 010052) and Klebsiella pneumoniae (RCMB 003-1) as Gram-negative bacteria and Staphylococcus aureus (RCMB 010010) and Bacillus subtilis (RCMB 015-1) as Gram-positive bacteria were used to evaluate the antibacterial activity of CNPs. Vero cells were supplied from the Tissues Culture Unit at VACSERA. Human adeno-40 and coxsackie B4 virus were provided from the Virology Laboratory at VACSERA to investigate the antiviral and virucidal activities of CNPs.

\section{Antibacterial activity of CNPs}

Agar diffusion methods were used to evaluate the antibacterial activity of CNPs against the tested bacteria (Valgas et al., 2007). Briefly, the bacterial inoculum $\left(10^{5} \mathrm{CFU} / \mathrm{ml}\right)$ was spread on a sterile Petri dish containing Mueller-Hinton agar. 50 $\mu \mathrm{l}$ of $1 \% \mathrm{CNPs}$ was added to a $6 \mathrm{~mm}$ hole in agar. The inhibition zone was measured in $\mathrm{mm}$ after incubation at $37^{\circ} \mathrm{C}$ for 24 hours.

The antibacterial action of CNPs against more sensitive bacteria was investigated using a TEM (JEOL 1010) at the RCMB, Al-Azhar University. The subcultural bacteria were treated with CNPs (500 and $62.5 \mu \mathrm{g} / \mathrm{ml}$ for B. subtilis and K. pneumoniae, resp.) and incubated for 24 hours at $37^{\circ} \mathrm{C}$. After the incubation and centrifugation for 15 minutes at $3,000 \times \mathrm{g}$, the precipitate was investigated under the electron microscopic examination through fixation, dehydration, embedment, polymerization, sectioning, and staining (Abdel-Razek, 2019).

\section{Cell viability}

The CNPs were tested on the viability of Vero cells by the 3-(4,5-dimethylthiazol-2-yl)-2,5-diphenyltetrazolium bromide (MTT) method (Bahuguna et al., 2017). Briefly, the Vero cells were incubated in a $96-$ well plate for 24 hours at $37^{\circ} \mathrm{C}$ in $5 \% \mathrm{CO}_{2}$. By culture media, the CNPs were diluted (2-fold dilution). The incubated cells were treated with CNPs dilution and culture media as treated and control groups, respectively, and then incubated again in the same conditions for the same period. $10 \mu \mathrm{l}$ MTT solution was added to each well and incubated for 4 hours in the same conditions. Then, $50 \mu \mathrm{l}$ dimethyl sulfoxide was added to each well and incubated at $37^{\circ} \mathrm{C}$ for a few minutes, and then by the Enzyme-Linked Immunosorbent Assay reader (BioTek, ELx800), the optical density (OD) was measured at $570 \mathrm{~nm}$. By Equation (2), the cell viability was calculated.

Cell viability $\%=($ mean OD of tested cells $/$ mean OD of control cells) $\times 100$

where OD is the optical density.

\section{Antiviral and virucidal activities of CNPs}

Antiviral and virucidal activities of CNPs were carried out against the tested viruses according to previous work (AbdelSamad, 2019). As for the antiviral activity, Vero cells (precultured into 96-well plate) were split into two sets. One set was handled with a safe concentration of CNPs (as the treated group), while another set was handled with culture media (as the control group). The handled cells were incubated for 24 hours at $37^{\circ} \mathrm{C}$, washed by 

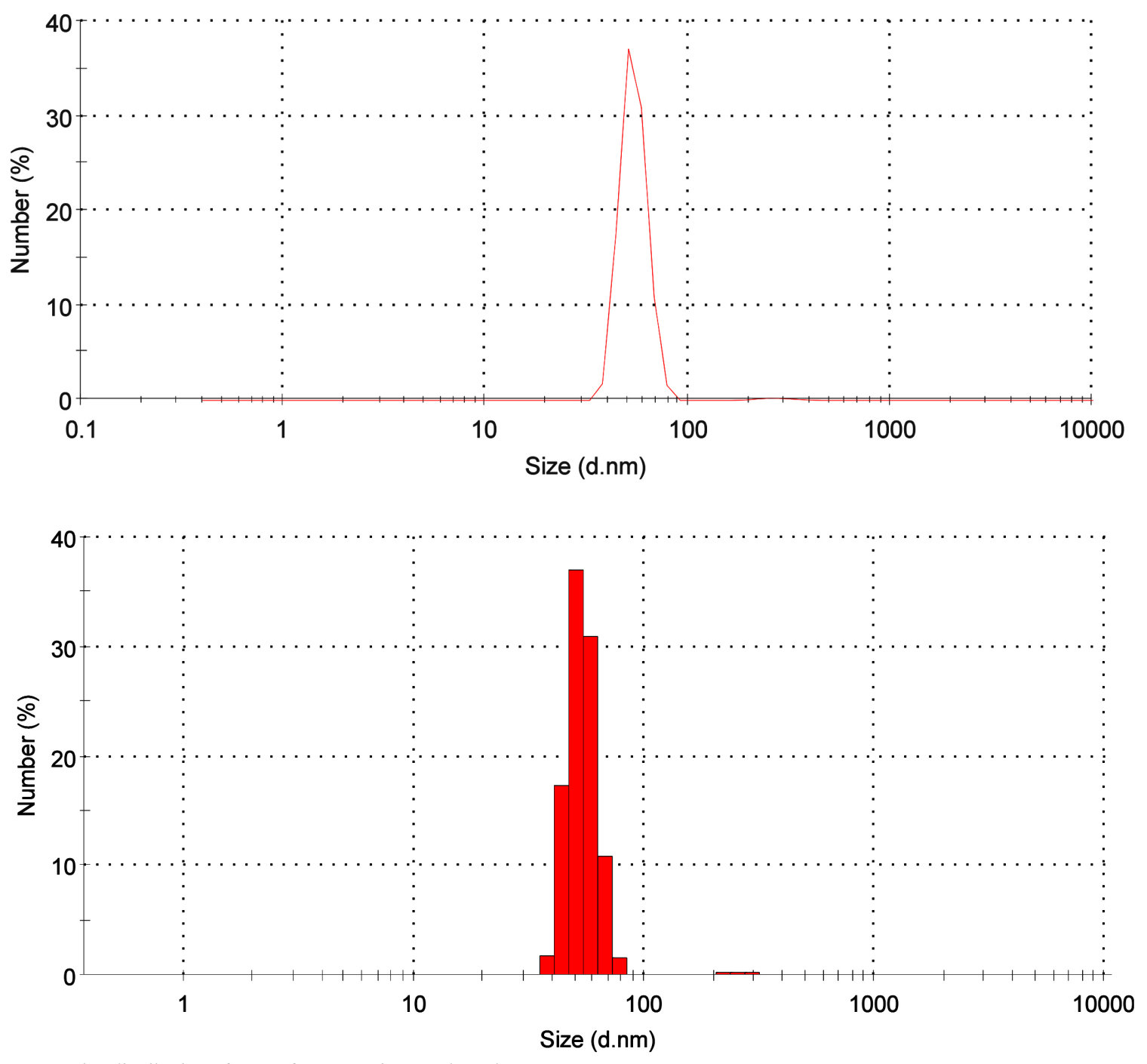

Figure 2. Size distribution of CNPs from American cockroaches.

Table 1. Antibacterial activity of CNPs.

\begin{tabular}{|c|c|c|c|c|}
\hline \multirow[b]{3}{*}{ Code } & \multicolumn{4}{|c|}{ Inhibition zone $($ mean \pm SD) $(\mathrm{mm})$} \\
\hline & \multicolumn{2}{|c|}{ Gram +ve bacteria } & \multicolumn{2}{|c|}{ Gram-ve bacteria } \\
\hline & $\begin{array}{c}\text { S. aureus } \\
\text { (RCMB 010010) }\end{array}$ & $\begin{array}{c}\text { B. subtilis } \\
\text { (RCMB 015-1) }\end{array}$ & $\begin{array}{c}\text { E. coli } \\
\text { (RCMB 010052) }\end{array}$ & $\begin{array}{l}\text { K. pneumoniae } \\
\text { (RCMB 003-1) }\end{array}$ \\
\hline CNPs & $10.99 \pm 0.48$ & $17.08 \pm 0.62$ & $19.08 \pm 0.51$ & $20.13 \pm 0.71$ \\
\hline
\end{tabular}

Dulbecco's phosphate-buffered saline, and then treated with the virus [multiplicity of infection $(\mathrm{MOI})=0.1$ ]. The titer of virus (in treated and control groups) was determined by the TCID standard method (Reed and Muench, 1938) after incubation for 24 hours at $37^{\circ} \mathrm{C}$.

For virucidal, equal volumes from the virus $(\mathrm{MOI}=0.1)$ and the safe concentration of CNPs were mixed and incubated for $1,3,6,18$, and 24 hours at $37^{\circ} \mathrm{C}$. The mixtures were added to Vero cells (previously cultured) and then incubated for 24 hours at $37^{\circ} \mathrm{C}$. The virus's titer was determined by the last-mentioned method.

\section{Statistical analysis}

The mean and standard deviation (SD) were used to display the data. GraphPad Prism version 8.0.2 was used to investigate the importance of differences between the values of the control and treated groups using a two-tailed independent Student's $t$-test. The threshold for statistical significance was set at $p<0.05$.

\section{RESULTS AND DISCUSSION}

\section{Characterization of chitosan}

The chemical structure of chitosan was confirmed by the FT-IR spectrum, where the main functional groups were detected 


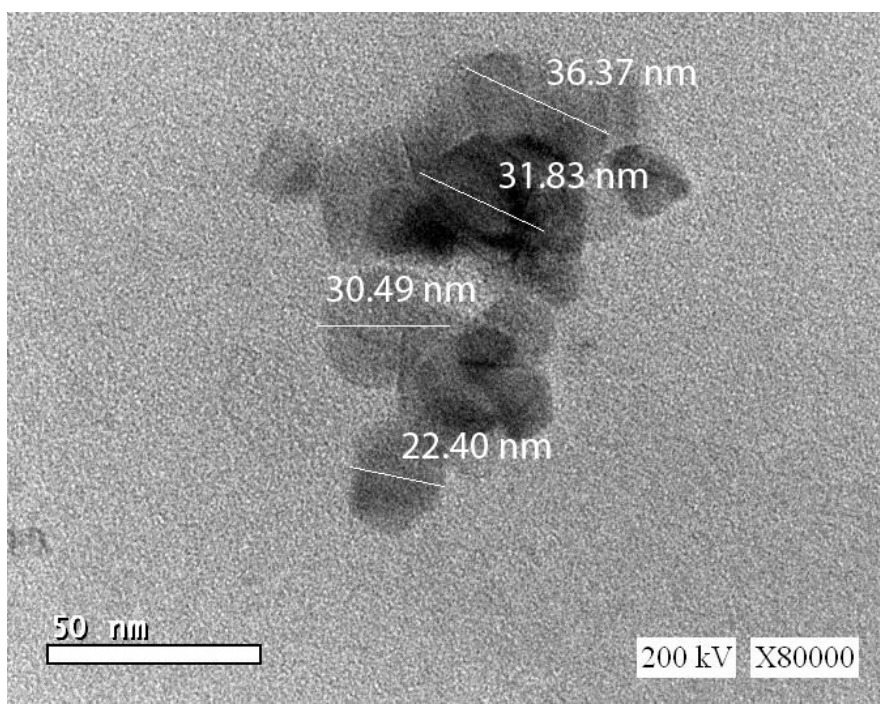

Figure 3. Transmission electron microscope (TEM) image of CNPs from American cockroaches.

(Fig. 1). Successful deproteinization was inferred by absorption absence at $1,540 \mathrm{~cm}^{-1}$ (Hassan et al., 2016b). Stretching of $\mathrm{NH}$ and $\mathrm{OH}$ free was observed at $3,433 \mathrm{~cm}^{-1}$ (Kaya et al., 2015), while the bending of $\mathrm{NH}\left(\mathrm{NH}_{2}\right)$ was represented at $1,629 \mathrm{~cm}^{-1}$ (Song et al., 2013). The absorption at 1,358 and $1,425 \mathrm{~cm}^{-1}$ bands was referred to as the symmetric and asymmetric stretching of $\mathrm{CH}$ $\left(\mathrm{CH}_{2}\right)$ (Gyliene et al., 2003), respectively, whereas the bending of this group was detected at 2,917 $\mathrm{cm}^{-1}$ (Liu et al., 2013). The vibration of the pyranose ring skeletal was observed at $899 \mathrm{~cm}^{-1}$ (Wanule et al., 2014), and the DDA was $74.51 \%$.

\section{Characterization of CNPs}

From DLS analysis, the distribution size of CNPs was figured with one main peak representing $99.3 \%$ of the whole sample. This peak ranged from 37.84 to $78.82 \mathrm{~nm}$, and the mean diameter was $54.12 \mathrm{~nm}$. There is another tiny peak with a diameter of 272.5 $\mathrm{nm}(0.7 \%)$ (Fig. 2). The polydispersity index of 0.6 indicates the monodispersability of CNPs (Stetefeld et al., 2016).

The TEM image showed the cubic shape of CNPs with a diameter ranging between 22.40 and $36.37 \mathrm{~nm}$ (Fig. 3). The slight decrease in the CNPs between DLS analysis and TEM investigation was due to a hydrodynamic diameter (Hassan et al., 2016b).

\section{Antibacterial activity CNPs}

The CNPs showed antibacterial activity against all tested bacteria, as presented in Table 1. A high inhibition zone was detected with $B$. subtilis and $K$. pneumoniae as Grampositive and Gram-negative bacteria, respectively. Generally, the

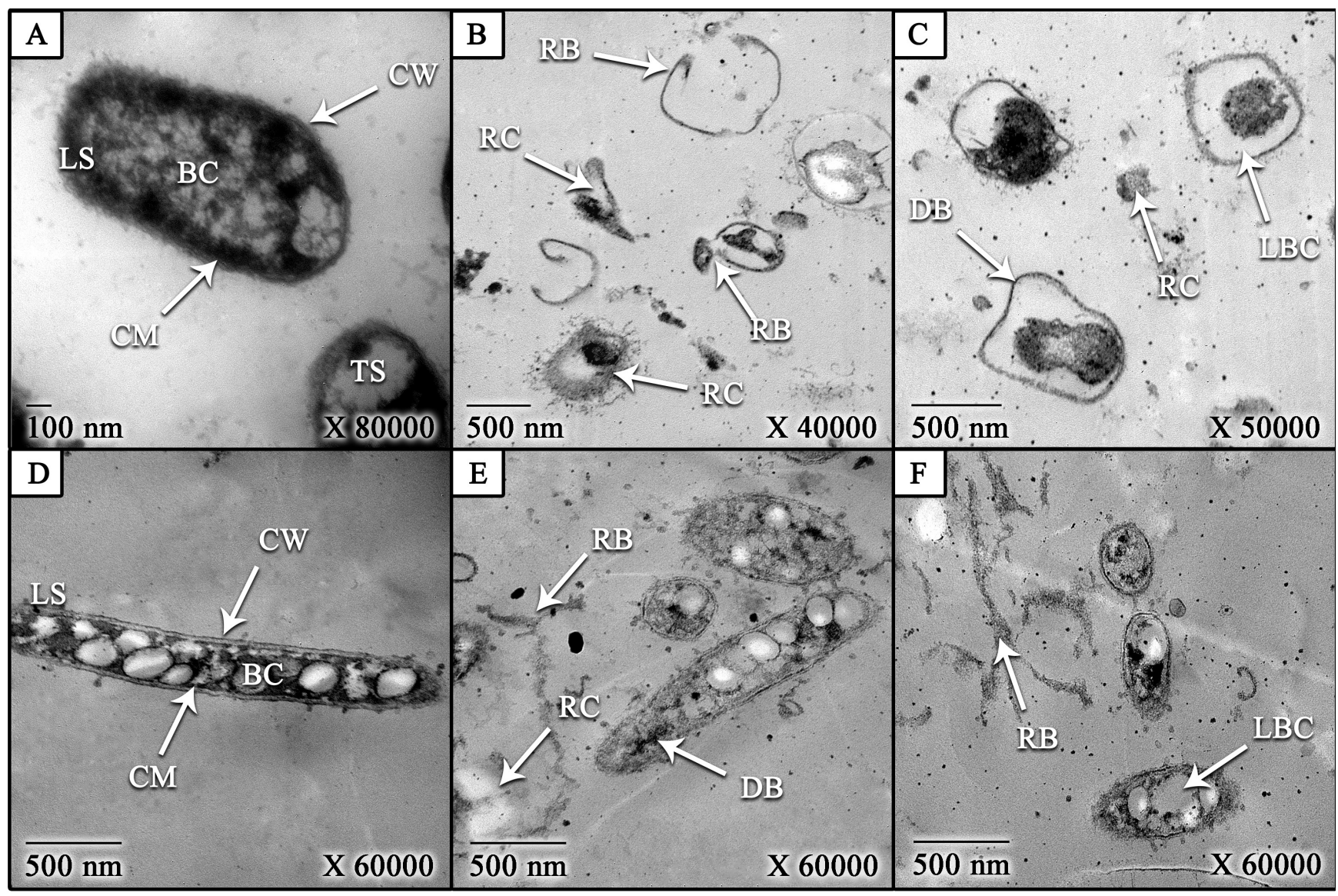

Figure 4. TEM images of treated and untreated $K$. pneumoniae and B. subtilis bacteria with CNPs [(A) untreated B. subtilis (control), (B and C) treated B. subtilis; (D) untreated K. pneumoniae (control), and (E and F) treated K. pneumonia]. LS: longitudinal section, TS: transverse section, CW: cell wall, CM: cell membrane, BC: bacterial contents, RB: ruptured bacteria, DB: deformed bacteria, LBC: leakage of bacterial contents, and RC: released contents. 


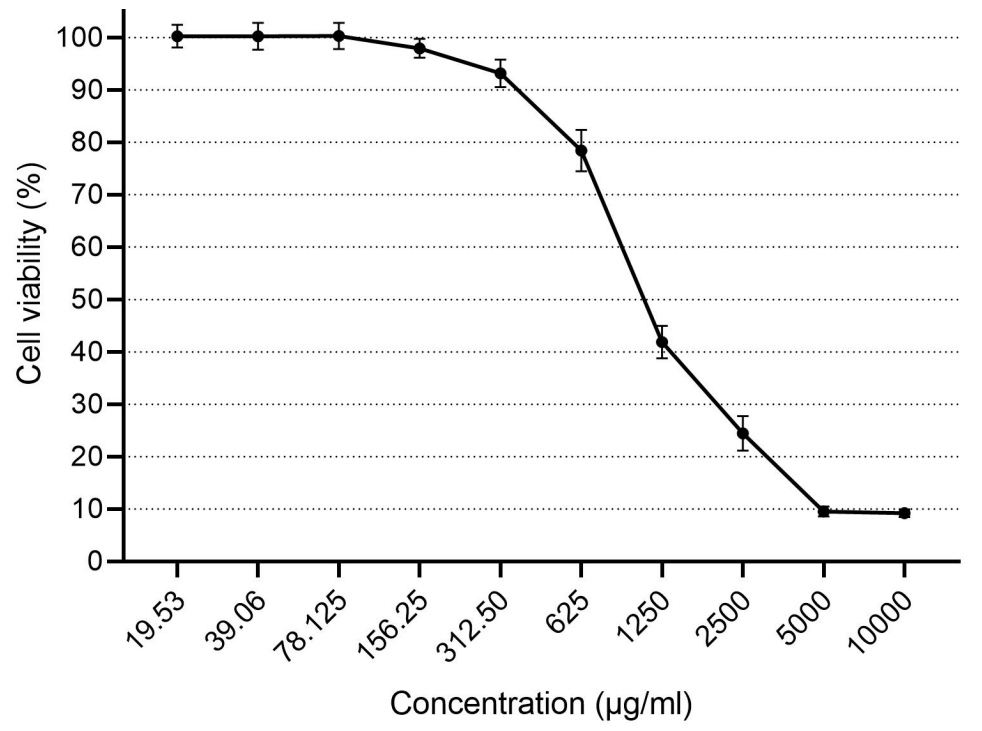

Figure 5. Cytotoxicity of CNPs from American cockroaches on the Vero cell line.
Adenovirus 40

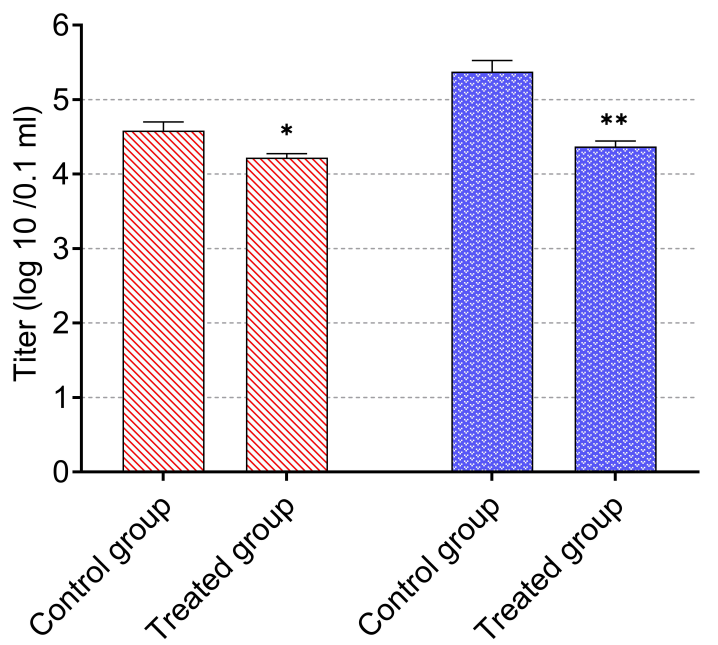

Figure 6. Antiviral activity of CNPs from American cockroaches against adeno-40 and coxsackie B4 viruses. The significance is analyzed by independent t-test $\left(* p<0.05,{ }^{*} p p<0.01\right.$, and $\left.* * * p<0.001\right)$.

Adenovirus 40

Coxsackie B4 virus

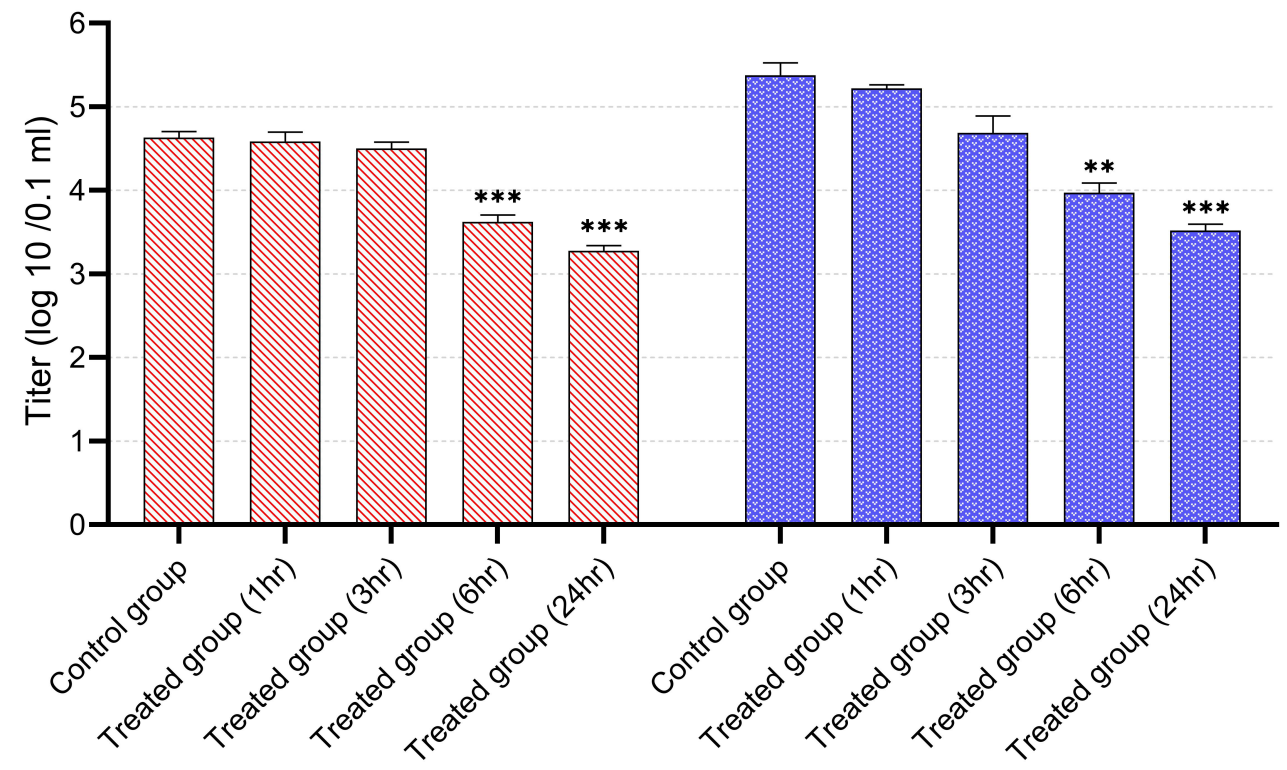

Figure 7. Virucidal activity of CNPs from American cockroaches against adeno-40 and coxsackie B4 viruses. The significance is analyzed by independent $t$-test $(* p<0.05, * * p<0.01$, and $* * * p<0.001)$.

Gram-negative bacteria were more delicate to the CNPs than the Gram-positive ones. Minimum inhibitory concentration values of CNPs were 4,000, 4,000, 1,000, and $500 \mu \mathrm{g} / \mathrm{ml}$ against $S$. aureus, B. subtilis, Escherichia E. coli, and Klebsiella K. pneumoniae, respectively.

As shown in Figure 4, the CNPs caused morphological changes on treated B. subtilis (Hassan et al., 2016b) and $K$. pneumoniae (Didenko et al., 2005; Hassan et al., 2016b). The bacterial contents were leaked due to increasing the cell permeability that also led to bacterial deformation and rupture of bacteria (Abdel-Razek, 2019; Hassan et al., 2016b; Liu et al.,
2004). The cell permeability was increased as a result of the electrostatic interaction between the positive charge of CNPs and the negative charge of the cell (Li et al., 2010; Wang et al., 2012). Moreover, the contrast between the size of CNPs and the bacterial size may have an impact on the antibacterial activity of CNPs (Hassan et al., 2016b).

\section{Cell viability}

Concerning cytotoxicity assessment of the CNPs, the Vero cells viability is contrarily corresponding with $\mathrm{CNP}$ concentration 
(Fig. 5). Cell viability (100\%) was detected at concentration $\leq 78$ $\mu \mathrm{g} / \mathrm{ml}$, whereas the concentrations of $125.25,312.5,625,1,250$, and $2,500 \mu \mathrm{g} / \mathrm{ml}$ showed viability $\approx 98 \%, 93 \%, 78 \%, 42 \%$, and $25 \%$. The high cytotoxicity percent $(\approx 90 \%)$ was observed at 5,000 and $10,000 \mu \mathrm{g} / \mathrm{ml}$.

\section{Antiviral and virucidal activities CNPs}

Infectivity titers of adeno- 40 and coxsackie B4 viruses as control were 4.6 and $5.4 \log (10) / 0.1 \mathrm{ml}$, respectively.

For antiviral activity, the infectivity titers of adeno-40 and coxsackie B4 viruses were reduced by a safe concentration of CNPs $(80 \mu \mathrm{g} / \mathrm{ml})$. As shown in Figure 6 , this concentration substantially reduced adenovirus infectivity titer to $4.2 \log (10) / 0.1$ $\mathrm{ml}(p<0.05)$ and coxsackie B4 virus infectivity titer to $4.4 \mathrm{log}$ $(10) / 0.1 \mathrm{ml}(p<0.01)$. The reduction percentages were about 5 and 26 for adeno- 40 and coxsackie B4 viruses, respectively.

In the virucidal activity, the CNPs $(80 \mu \mathrm{g} / \mathrm{ml})$ demonstrated a significant reduction in adeno-40 and coxsackie B4 virus's infectivity titers after incubation for 6 and 24 hours. Typically, after $1,3,6$, and 24 hours of incubation with this concentration, the adeno-40 virus titer decreased to $4.6,4.5,3.6$, and $3.3 \log (10) / 0.1$ $\mathrm{ml}$, respectively, while the titer of coxsackie B4 virus was 5.2, 4.7, 3.9, and $3.5 \log (10) / 0.1 \mathrm{ml}$, respectively (Fig. 7).

In the present study, the CNPs from American cockroaches protected the Vero cells from the cytopathic effect of adeno-40 and coxsackie B4 viruses, and it showed antiviral activity and suppressed the viral infection (Ai et al., 2012; Chirkov, 2002; Hassan et al., 2016). Also, the chitosan can protect from 3 influenza strains: H7N9, H1N1, and H9N2 (Zheng et al., 2016), and it has been proposed as a potential universal antiviral agent. Moreover, the chitosan derivatives may be used as new HIV drug candidates (Artan et al., 2008). Davydova et al. (2011) noted that the antiviral activity of chitosan is influenced by DA. Chitosan was discovered to significantly decrease the infectivity of the feline calicivirus FCV-F9, as well as the bacteriophages MS2 and phiX174 (Davis et al., 2012). Beta-chitosan has a promising development in veterinary medicines to treat Newcastle disease (He et al., 2016).

\section{CONCLUSION}

This study shows the effect of CNPs prepared from American cockroaches on E. coli, K. pneumoniae, S. aureus, and B. subtilis, as well as adeno-40 coxsackie B-4 viruses. CNPs were prepared by ball-milling from $74.51 \%$ DDA chitosan. The chitosan showed antibacterial activity and caused the deformation and rupture of bacteria. Furthermore, the CNPs protected the Vero cells and decreased the infectivity titer of adeno-40 and coxsackie B-4 virus. We recommend applying CNPs from American cockroaches as an antimicrobial agent in the management of infectious diseases.

\section{AUTHOR CONTRIBUTIONS}

Mahmoud T Mahboub: data acquisition; drafting manuscript; admin, technical, or material support; final approval. Mostafa I. Hassan: concept and design; critical revision of the manuscript; supervision; final approval. Ahmed S. Bream: supervision; final approval. Aly F. Mohamed: data acquisition; data analysis/interpretation; statistical analysis; admin, technical, or material support; supervision; final approval. Mohammad R. K. Abdel-Samad: concept and design; data acquisition; data analysis/ interpretation; critical revision of the manuscript; statistical analysis; admin, technical, or material support; supervision; final approval.

\section{CONFLICT OF INTEREST}

The authors state that they have no conflict of interest.

\section{FUNDING}

No funding was obtained for this study.

\section{ETHICAL APPROVAL}

This study does not involve experiments on animals or human subjects.

\section{REFERENCES}

Abdel-Razek N.Antimicrobial activities of chitosan nanoparticles against pathogenic microorganisms in Nile tilapia, Oreochromis niloticus Aquac Int, 2019; 27:1315-30; doi:10.1007/s10499-019-00388-0

Abdel-Samad MRK. Antiviral and virucidal activities of Lucilia cuprina maggots' excretion/secretion (Diptera: Calliphoridae): first work. Heliyon, 2019; 5:e02791; doi:10.1016/j.heliyon.2019.e02791

Ai H, Wang F, Xia Y, Chen X, Lei C. Antioxidant, antifungal and antiviral activities of chitosan from the larvae of housefly, Musca domestica L. Food Chem, 2012; 132:493-8; doi:10.1016/j.foodchem.2011.11.033

Artan M, Karadeniz F, Kim MM, Kim SK. Chitosan derivatives as HIV-1 inhibitors. J Biotechnol, 2008; 136:S539; doi:10.1016/j. jbiotec.2008.07.1268

Bahuguna A, Khan I, Bajpai VK, Kang SC. MTT assay to evaluate the cytotoxic potential of a drug. Bangladesh J Pharmacol, 2017; 12:115-8; doi:10.3329/bjp.v12i2.30892

Baxter A, Dillon M, Anthony Taylor KD, Roberts GAF. Improved method for i.r. determination of the degree of $\mathrm{N}$-acetylation of chitosan. Int J Biol Macromol, 1992; 14:166-9; doi:10.1016/S0141-8130(05)80007-8

Chatelet C, Damour O, Domard A. Influence of the degree of acetylation on some biological properties of chitosan films. Biomaterials, 2001; 22:261-8; doi:10.1016/S0142-9612(00)00183-6

Chen S, Wei X, Sui Z, Guo M, Geng J, Xiao J, Huang D. Preparation of antioxidant and antibacterial chitosan film from Periplaneta americana. Insects, 2021; 12:1-14; doi:10.3390/insects 12010053

Chirkov SN. The Antiviral activity of chitosan (review). Prikl Biokhimiya i Mikrobiol, 2002; 38:12-3.

Davis R, Zivanovic S, D’Souza DH, Davidson PM. Effectiveness of chitosan on the inactivation of enteric viral surrogates. Food Microbiol, 2012; 32:57-62; doi:10.1016/j.fm.2012.04.008

Davydova VN, Nagorskaya VP, Gorbach VI, Kalitnik AA, Reunov A V, Solov'eva TF, Ermak IM. Chitosan antiviral activity: dependence on structure and depolymerization method. Appl Biochem Microbiol, 2011; 47:103-8; doi:10.1134/S0003683811010042

Didenko LV, Gerasimenko DV, Konstantinova ND, Silkina TA, Avdienko ID, Bannikova GE, Varlamov VP. Ultrastructural study of chitosan effects on Klebsiella and Staphylococci. Bull Exp Biol Med, 2005; 140:356-60; doi:10.1007/s10517-005-0489-6

Gyliene O, Razmute I, Tarozaite R, Nivinskiene O. Chemical composition nd sorption properties of chitosan produced from fly larva shells. Chemija, 2003; 14:121-7.

Hassan Mostafa I, Mohamed AF, Taher FA, Kamel MR. Antimicrobial activities of chitosan nanoparticles prepared from Lucilia cuprina maggots (Diptera: Calliphoridae). J Egypt Soc Parasitol, 2016a; 46:563-70; doi:10.12816/0033977 
Hassan Mostafa I, Taher FA, Mohamed AF, Kamel MR. Chitosan nanoparticles prepared from Lucilia cuprina maggots as antibacterial agent. J Egypt Soc Parasitol, 2016b; 46:519-26; doi:10.12816/0033971

He X, Xing R, Li K, Qin Y, Zou P, Liu S, Yu H, Li P. Betachitosan extracted from Loligo Japonica for a potential use to inhibit Newcastle disease. Int J Biol Macromol, 2016; 82:614-20; doi:10.1016/j. ijbiomac.2015.10.059

Kamal M, Adly E, Alharbi SA, Khaled AS, Rady MH, Ibrahim NA. Exploring simplified methods for insect chitin extraction and application as a potential alternative bioethanol resource. Insects, 2020; 11:1-14; doi:10.3390/insects11110788

Kaya M, Baran T, Asan-Ozusaglam M, Cakmak YS, Tozak KO, Mol A, Mentes A, Sezen G. Extraction and characterization of chitin and chitosan with antimicrobial and antioxidant activities from cosmopolitan Orthoptera species (Insecta). Biotechnol Bioprocess Eng, 2015; 20:168-79; doi:10.1007/s12257-014-0391-z

Kim I, Seo S, Moon H, Yoo M, Park I, Kim B, Cho C. Chitosan and its derivatives for tissue engineering applications. Biotechnol Adv, 2008; 26:1-21; doi:10.1016/j.biotechadv.2007.07.009

Lashley FR. Emerging infectious disease: vulnerabilities, contributing factors and approaches. Expert Rev Anti Infect Ther, 2004; 2:299-316; doi:10.1586/14787210.2.2.299

Leceta I, Guerrero P, De La Caba K. Functional properties of chitosan-based films. Carbohydr Polym, 2013; 93:339-46; doi:10.1016/j. carbpol.2012.04.031

Lee H, Hwang JS, Lee DG. Periplanetasin-4, a novel antimicrobial peptide from the cockroach, inhibits communications between mitochondria and vacuoles. Biochem J, 2019; 476:1267-84; doi:10.1042/ BCJ20180933

Li X, Feng X, Yang S, Fu G, Wang T, Su Z. Chitosan kills Escherichia coli through damage to be of cell membrane mechanism. Carbohydr Polym, 2010; 79:493-9; doi:10.1016/j.carbpol.2009.07.011

Liu H, Du Y, Wang X, Sun L. Chitosan kills bacteria through cell membrane damage. Int J Food Microbiol, 2004; 95:147-55; doi:10.1016/j. ijfoodmicro.2004.01.022

Liu M, Zhou Y, Zhang Y, Yu C, Cao S. Preparation and structural analysis of chitosan films with and without sorbitol. Food Hydrocoll, 2013; 33:186-91; doi:10.1016/j.foodhyd.2013.03.003

Marei NH, El-Samie EA, Salah T, Saad GR, Elwahy AHM. Isolation and characterization of chitosan from different local insects in Egypt. Int J Biol Macromol, 2016; 82:871-7; doi:10.1016/j.ijbiomac.2015.10.024

Meng Q, Sun Y, Cong H, Hu H, Xu FJ. An overview of chitosan and its application in infectious diseases. Drug Deliv Transl Res, 2021; 11: 1340-51; doi:10.1007/s13346-021-00913-w

Mohan K, Ganesan AR, Muralisankar T, Jayakumar R, Sathishkumar P, Uthayakumar V, Chandirasekar R, Revathi N. Recent insights into the extraction, characterization, and bioactivities of chitin and chitosan from insects. Trends Food Sci Technol, 2020; 105:17-42; doi:10.1016/j.tifs.2020.08.016

Mosaheb MUWFZ, Khan NA, Siddiqui R. Cockroaches, locusts, and envenomating arthropods: a promising source of antimicrobials. Iran J Basic Med Sci, 2018; 21:873-7; doi:10.22038/ijbms.2018.30442.7339

Peniche H, Peniche C. Chitosan nanoparticles: a contribution to nanomedicine. Polym Int, 2011; 60:883-9; doi:10.1002/pi.3056
Qi L, Xu Z, Jiang X, Hu C, Zou X. Preparation and antibacterial activity of chitosan nanoparticles. Carbohydr Res, 2004; 339:2693-700; doi:10.1016/j.carres.2004.09.007

Reed LJ, Muench H. A simple method of estimating fifty per cent endpoints. Am J Epidemiol, 1938; 27:493-7

Song C, Yu H, Zhang M, Yang Y, Zhang G. Physicochemical properties and antioxidant activity of chitosan from the blowfly Chrysomya megacephala larvae. Int J Biol Macromol, 2013; 60:347-54; doi:10.1016/j. ijbiomac.2013.05.039

Stetefeld J, McKenna SA, Patel TR. Dynamic light scattering: a practical guide and applications in biomedical sciences. Biophys Rev, 2016; 8:409-27; doi:10.1007/s12551-016-0218-6

Valgas C, De Souza SM, Smânia EFA, Smânia A. Screening methods to determine antibacterial activity of natural products. Brazilian J Microbiol, 2007; 38:369-80; doi:10.1590/S1517-83822007000200034

Vinsova J, Vavrikova E. Chitosan derivatives with antimicrobial, antitumour and antioxidant activities - a review. Curr Pharm Des, 2011; 17:3596-607; doi:10.2174/138161211798194468

Wang Y, Li L, Li B, Wu G, Tang Q, Ibrahim M, Li H, Xie G, Sun G. Action of chitosan against Xanthomonas pathogenic bacteria isolated from Euphorbia pulcherrima. Molecules, 2012; 17:7028-41; doi:10.3390/ molecules 17067028

Wanule D, Balkhande J V, Ratnakar PU, Kulkarni a. N, Bhowate CS. Extraction and FTIR analysis of chitosan from American cockroach, Periplaneta americana. Int J Eng Sci Innov Technol, 2014; 3:299-304.

Zhang W, Zhang J, Xia W. Effect of ball-milling treatment on physicochemical and structural properties of chitosan. Int J Food Prop, 2014; 17:26-37; doi:10.1080/10942912.2011.608175

Zheng M, Qu D, Wang H, Sun Z, Liu X, Chen J, Li C, Li X, Chen Z. Intranasal administration of chitosan against influenza A (H7N9) virus infection in a mouse model. Sci Rep, 2016; 6:1-11; doi:10.1038/srep28729

How to cite this article:

Mahboub MT, Hassan MI, Bream AS, Mohamed AF, AbdelSamad MRK. Antibacterial and antiviral activities of chitosan nanoparticles from the American cockroach, Periplaneta americana. J Appl Pharm Sci, 2022; 12(03):202-208. 